Stefan Szary

Collegium Da Vinci w Poznaniu

\title{
Zagadnienie myślenia i odpowiedzialności w filozoficznej refleksji Hannah Arendt
}

Bez oddechu życia ludzkie ciało umiera; bez myślenia umyst ludzki jest martwy.

Hannah Arendt, Życie umystu

Hannah Arendt (1906-1975) należy do grona uczonych, których refleksje zwykle odbierane są przez czytelników jako jasne i zrozumiałe, co nie jest w świecie nauki całkiem oczywiste. Warto najpierw podkreślić, że Arendt odebrała rzetelne wykształcenie filozoficzne. Krytykę czystego rozumu Immanuela Kanta czytała już jako czternastolatka. W wieku lat szesnastu znała języki grecki i łaciński w takim stopniu, że mogła czytać literaturę antyczną. Jeszcze przed przystąpieniem do egzaminu dojrzałości w Berlinie słuchała Romano Guardiniego i podjęła studium dzieł prekursora filozofii egzystencji Sørena Kierkegaarda. Właśnie w Berlinie po raz pierwszy usłyszała o Martinie Heideggerze. Po złożeniu egzaminu maturalnego rozpoczęła w 1924 roku studia w Marburgu. Postanowiła zgłębić trzy kierunki: filozofię u Heideggera, teologię u Rudolfa Bultmanna oraz język grecki [Heuer 1987: 15-19; Safranski 2008: 159-160]. Was heißt Denken? - Co zwie się myśleniem? pytał podczas wykładów prowadzonych w latach 1951-1952 Heidegger. Arendt nie tylko zgłębiła ten problem: czym jest myślenie, co jest jego istotą i na czym ono polega, lecz także za fundament poszukiwań naukowych uznała życie umysłu - vita contempla- 
tiva - i życie woli - vita activa. Heidegger podkreślał rolę nastroju, który w pewien sposób wpływa na jakość myślenia. W przypadku Arendt refleksja o myśleniu zrodziła się z jego umiłowania - $\varphi \iota \lambda \tilde{\varepsilon} \tilde{v}$ бoфía. Źródłowym nastrojem „dla myślenia o myśleniu” była dla niej miłość myślenia, co wydaje się uzasadniać zarówno pragnienie studiowania filozofii, jak i studiowanie jej pod kierunkiem Heideggera.

Wieść o Heideggerze [wspomina Arendt - S.S.] przedstawiała sprawę całkiem prosto: myślenie zostało wskrzeszone; skarby dawnej kultury uchodzące za martwe, przemówiły; okazało się, że mówią one coś całkiem nowego, nie powtarzają owych banałów, które dotąd im przypisywano. Jest nauczyciel; być może on nauczy myślenia. [Arendt 1974: 693]

Więź filozoficzna połączyła Arendt i Heideggera', a stało się to w okresie, gdy myśliciel pracował nad Sein und Zeit. Rüdiger Safranski [2008: 163-164] pisał: „[Heidegger - S.S.] traktował ją [Arendt - S.S.] poważnie jako kobietę, która go rozumie; ona stała się dla niego muzą w Byciu i czasie; bez niej to dzieło nie mogłoby zostać napisane”.

Celem pracy stała się identyfikacja charakterystycznego dla twórczości Arendt związku łączącego myślenie, stanowiące przestrzeń indywidualnej, a nawet intymnej refleksji, wyrażonej poprzez vita contemplativa, z osobistą odpowiedzialnością za własne czyny i działanie, rozumiane jako vita activa. Postawiono zarazem pytania problemowe: czym według Arendt jest myślenie? Jaka relacja zachodzi pomiędzy myśleniem a działaniem? Czym jest odpowiedzialność i na czym ona polega? Choć tak sformułowane pytania mogą wydawać się banalne, to właśnie od tych pozornie błahych spraw i sposobu ich rozumienia zależą, zgodnie z przekonaniem Arendt, najważniejsze wybory człowieka i funkcjonowanie świata; zwłaszcza te wybory, od których wprost zależy ludzkie życie.

1 W pracy pominięto wątek osobistej relacji uczuciowej Arendt i Heideggera. Temat ten został przedstawiony w publikacji Elżbiety Ettinger [1998], Hannah Arendt - Martin Heidegger. 
Punktem wyjścia w tak nakreślonej perspektywie jest opublikowana w 1963 roku praca Arendt Eichmann w Jerozolimie. Rzecz o banalności zła. Ponieważ jest ona szeroko komentowana w literaturze ${ }^{2}$, w niniejszej refleksji sięgnięto do innych ważnych dzieł Autorki, do których należą m.in. Życie umysłu, Kondycja ludzka oraz Odpowiedzialność $i$ wtadza sq̨dzenia. Refleksji poddano kolejno formulowane przez Arendt ujęcia: miłości myślenia, służby myśleniu i samej odpowiedzialności, co w konkluzji doprowadziło do próby filozoficznej weryfikacji symbiozy myślenia i odpowiedzialności.

Myślenie nie oznacza bynajmniej odwołania się do kwestii abstrakcyjnych, lecz wiąże się bezpośrednio z „u-chwytywaniem istoty życia”, także - a może przede wszystkim - wtedy, kiedy człowiek - posłużę się określeniem Heideggera - zostaje „w-rzucony” w sytuację dramatu. W tych szczególnych okolicznościach podstawowym pytaniem staje się - die Frage nach dem Sinn von Sein pytanie o sens istnienia, o sens egzystencji konkretnego człowieka w jego rzeczywistej sytuacji.

\section{Miłość myślenia}

Miłość poszukująca mądrości, oznaczająca - zwłaszcza u filozofów greckich - tęsknotę, to zarazem pełne uwagi i skupienia „wy-czekiwanie" chwili, w której oo moment ten w ogóle nastąpi, w skupieniu „wy-czekującym”. Warto podkreślić, że do pojęcia prawdy, rozumianej jako á $\lambda \dot{\eta} \theta \varepsilon ı$, czyli odsłonięcie, często nawiązywał Heidegger. Ponadto, odwołując się do Uczty Platona, można powiedzieć, że człowiek myślący w pewnym momencie uświadamia sobie, iż nie jest posiadaczem mądrości, i zarazem stara się uciec przed głupotą. Głupi żyje bowiem w iluzorycznym przekonaniu, że jest mądry, a zatem nie musi już żadnej mądrości szukać, pragnąć ani wyczekiwać, gdyż on ją po prostu ma. Nic nie przeraża filozofów bardziej niż głupota. Za niczym też bardziej filozofowie nie tęsknią, jak za mądrością. Tęsknotę tę

2 Na ten temat powstały m.in. takie prace, jak Hannah Arendt: Legal Theory and the Eichmann Trial [Burdon 2017] i Der Eichmann-Prozess. Der Begriff des Handelns und seine Konsequenzen nach Hannah Arendt [Hey 2017]. 
wydaje się odzwierciedlać życie Arendt - urzeczone mądrością a zarazem jej twórczość, odzwierciedlająca swoisty spór. Autorka udokumentowała różnorodne sytuacje dramatycznego napięcia wyrażone słowem „pomiędzy”: pomiędzy mądrością a głupotą, narodzinami a śmiercią, pomiędzy dobrem a złem, nadzieją a rozpaczą, pomiędzy sensem a bezsensem, byciem a nicością. Owo „pomiędzy” wyraźnie wskazuje na człowieka, określanego przez Heideggera terminem Da-sein, oznaczającym bycie przytomne, świadome drogi, której trzeba szukać i którą warto kroczyć. Droga rozumiana jest w tym kontekście jako metafora przyszłości, u której kresu na każdego „wy-czekuje” jego własna śmierć. Da-sein als Sein-zum-Tode. Warto zauważyć, że interpretacja Arendt wydaje się znaczenie bliższa ujęciu Kierkegaarda, a zarazem odmienna od ujęcia Heideggera. Autorka stwierdza:

Końcem życia jest śmierć, lecz człowiek nie żyje dla śmierci, lecz dlatego, że jest istotą żyjącą; i nie myśli po to, by osiągnąć jakikolwiek wynik, ale dlatego, że jest „istotą myślącą to znaczy rozmyślającą”. [Arendt 1974: 695]

Arendt odsyła egzystencjalne „pomiędzy” wprost do kategorii „albo - albo”, która oznacza sytuację wyboru. Wszelka próba ucieczki przed podejmowaniem decyzji jest także wyborem, choć okazuje się wyborem tragicznym. Jest to bowiem wybór ucieczki przed wolnością - a więc przed sobą samym.

Miłość myślenia, które realizuje się w vita contemplativa, powinna być źródłem ludzkiego działania - vita activa. Działanie pozbawione myślenia prowadzi najczęściej do bezmyślności, co wcale nie oznacza wyłączenia odpowiedzialności lub przerzucenia jej na kogoś innego.

\section{Służba myśleniu}

Da-sein, świadome własnego „tu i teraz”, ogarnia zatem minioną bezpowrotnie przeszłość, a także projekty wybiegające w przyszłość. Równocześnie teraźniejszość nieustannie wymyka się wszelkiej próbie „złapania” i tym samym „zamrożenia”. Życie więc 
staje się, jest in statu nascendi. Podobnie proces autentycznego myślenia dokonuje się w swoistej dla siebie dynamice, w blasku światła. Metafora światła odgrywa w filozofii, a także w teologii rolę bezprecedensową. Platon określa słońce jako symbol tego, co najważniejsze, a więc życiodajne, otwierające wszelką perspektywę i możność widzenia. Najważniejszą ideą dla Platona było Dobro.

Więc ja - dodałem - słońce nazywam dzieckiem Dobra; Dobro je zrodziło na podobieństwo własne i tym, czym jest Dobro w świecie myśli i przedmiotów myśli, tym jest słońce w świecie widzialnym w stosunku do wzroku i do tego, co się widzi. [Platon 1999: 47]

Światło słońca wskazuje na Dobro. Człowiek realizujący ideę Dobra, według Platona, żyje życiem rozumnym. Rozum zaś bezpośrednio skłania do myślenia. Człowiek, posiadacz rozumu, wezwany jest zatem do myślenia, tzn. do rozmyślania. Powraca więc pytanie Heideggera: Was heißt Denken? Bez myślenia nie ma vita vera-życia prawdziwego - ani żadnych dla niego perspektyw. Maneat quaestio? Oznacza to konieczność stawiania pytań, co wyjaśnia Heidegger [2002: 46]: „[...] denn das Fragen ist die Frömmigkeit des Denkens” - „[... ] albowiem zapytywanie jest pobożnością myślenia”.

Arendt zachęca, a może nawet prowokuje do rzetelnego myślenia. Inspiruje do filozoficznych poszukiwań - nie z próżności ani pragnienia wiedzy dla wiedzy, lecz w poczuciu odpowiedzialności za człowieka, którego zadaniem jest budowanie autentycznego ja. Arendt nadała nowe znaczenie greckiej $\pi a \iota \delta \varepsilon i$ poprzez wyeksplikowanie tego, co powinno zostać wydobyte z cienia, z ukrycia, ze skrytości - prawdy jako á $\lambda \dot{\theta} \theta \varepsilon$ ı́.

Kiedy próbujemy zrozumieć i nakreślić przestrzeń refleksji Arendt, największą trudność stanowi udzielenie odpowiedzi na pytanie: Jak mówić o Arendt, by zarazem nie zniszczyć i nie pomniejszyć bogactwa myśli, które przekazała w napisanych dziełach i udzielonych wywiadach? W tym kontekście próba pomyślenia „razem z” oraz „w duchu” Arendt, przede wszystkim w odniesieniu do wciąż inspirującego tekstu Życie umystu, wydaje się uzasadniona i potrzebna. 


\section{Odpowiedzialność}

Zaszeregowanie Arendt do jednego tylko nurtu, dziedziny czy światopoglądu nie wydaje się możliwe. Jej teksty można odczytywać przez pryzmat historii idei, a zarazem w perspektywie filozofii egzystencji, myśli politycznej, etycznej i innych. Podczas analizowania metody Arendt można dostrzec wpływ fenomenologii. Chodzi w niej o to, by po pierwsze: dostrzec, zobaczyć, dojrzeć


zawieszenia sądu co do istnienia [Husserl 1975: 92-94] - ale przede wszystkim istotę „bycia bytu”, czyli Da-sein [Heidegger 1994]), po drugie: adekwatnie opisać to, co źródłowo dane jest w doświadczeniu - ogląd i opis ejdetyczny. Pisze Arendt [2016: 88]: „Widzieć to idein, a znać - eidenai, czyli «mieć» zobaczone. Najpierw się widzi, potem się zna”. Dzięki temu można w ogóle spróbować „coś” opisać. Ponownie zauważono, że perspektywa Arendt różni się od podejścia stosowanego przez Heideggera. In-der-Welt-Sein („bycie -w-świecie”) oznacza dla niej świadomość dzielenia i kształtowania świata razem $\mathrm{z}$ innymi. Człowiek nie jest zamkniętą monadą. $\mathrm{Z}$ tego powodu fundamentalne znaczenie ma zagadnienie odpowiedzialności [Safranski 2008: 421].

Spróbujmy zatem - na wzór Arendt - najpierw zobaczyć i rozpoznać drugi, obok myślenia, kluczowy aspekt refleksji filozoficznej dotyczący odpowiedzialności³. Dramatyczny jej obraz Autorka przywołuje w Auschwitz przed sądem, pracy opublikowanej w 1966 roku. Przypomnijmy przedstawione w niej okoliczności, odwołując się do studium przypadku popartego oryginalnym tekstem Arendt. W okresie od 20 grudnia 1963 roku do 10 sierpnia 1965 roku we Frankfurcie nad Menem toczył się „drugi proces oświęcimski”, podczas którego na ławie oskarżonych zasiadło dwudziestu człon-

Warto w tym miejscu przywołać stanowisko Jeana Améry'ego - torturowanego w Breendonk, a następnie więzionego w Auschwitz, Buchenwaldzie i Bergen-Belsen - które zostało wyrażone w książce Poza wina i kara. W nawiązaniu do stwierdzenia Arendt o „banalności zla” Améry [2007: 72] napisał: „Nie ma bowiem czegoś takiego jak «banalność zła», a Hannah Arendt, która napisała o tym w swojej książce o Eichmannie, znała tego ludobójcę jedynie ze słyszenia i widziała go tylko przez pancerne szkło klatki”. 
ków załogi niemieckiego obozu koncentracyjnego Auschwitz-Birkenau. Wśród nich znajdował się lekarz obozowy Franz Lukas. Na tej postaci koncentruje się komentarz Arendt:

[... Lucas pomagał ludziom od początku do końca; przed sądem zaś nie tylko nie pozował na „wybawcę" - w przeciwieństwie do większości oskarżonych - ale konsekwentnie odmawiał przyznania racji świadkom, którzy zeznawali na jego korzyść, i twierdzil, że nie pamięta wspominanych przez nich wydarzeń. Podczas pracy w obozie omawial panujące tam warunki sanitarne $\mathrm{z}$ więźniami-lekarzami, zwracając się do nich per „panie doktorze”, wykradał nawet z apteki ss lekarstwa dla więźniów, „kupował im za własne pieniądze jedzenie” i dzielił się z nimi swoją racją żywnościową; „był jedynym lekarzem, który traktował ich po ludzku”, „,nie patrzył na nich jak na istoty gorszego gatunku” i doradzał osadzonym w obozie lekarzom, w jaki sposób „ratować innych więźniów od komór gazowych”. Jak podsumował jeden ze świadków: „Byliśmy zrozpaczeni, kiedy doktor Lucas wyjechał. Dopóki był z nami, byliśmy tak weseli. Doprawdy, znów nauczyliśmy się śmiać”. [...] Kiedy Lucas po raz pierwszy zapoznał się ze swoimi obowiązkami w Auschwitz, zaczął szukać porady: najpierw u swojego biskupa, który powiedział mu, że „nie wolno wykonywać niemoralnych poleceń, co nie oznacza, że trzeba narażać własne życie”; następnie zaś u wysokiej rangi prawnika, który usprawiedliwiał obozowe okropieństwa tym, że jest wojna. Obaj niewiele mu więc pomogli. Ale przypuśćmy, że Lucas zapytałby więźniów, co ma robić. Czyż nie błagaliby go, żeby został - za cenę uczestnictwa w selekcjach (które, choć koszmarne, byly wydarzeniem codziennym, niejako rutynowym) - i uchronił ich od prymitywnej, szatańskiej pomysłowości wszystkich innych pracowników obozu. [Arendt 2006: 278-279]

Autorka wskazuje na centrum dramatu owej sytuacji „pomiędzy”. Widać w niej przynajmniej dwie perspektywy, wzajemnie wykluczające się. Dramat odpowiedzialności wieńczy swoista 
tragedia. Obraz ten rozwija Arendt [2006: 285], przedstawiając dylemat Lucasa:

Oto wreszcie kobieta, która przyjechała do Frankfurtu z Miami, bo czytała gazety i zobaczyła nazwisko doktora Lucasa. „Interesuje mnie człowiek, który zamordował moją matkę i rodzeństwo" - mówi. I wyjaśnia, jak do tego doszło. Do obozu przybyła z Węgier w 1944 roku. „Trzymałam na rękach dziecko. Mówili, że matki mogą zostać z dziećmi, więc moja matka dała mi maleństwo i ubrała tak, żebym wyglądała na starszą. Kiedy doktor Lucas mnie zobaczył, prawdopodobnie zorientował się, że dziecko nie jest moje. Zabrał mi je i rzucił mojej matce”. Sąd natychmiast domyśla się prawdy. „A więc odważył się pan uratować świadkowi życie?” Lucas przez chwilę milczy, a potem wszystkiemu zaprzecza. Kobieta zaś, najwyraźniej nadal nieznająca reguł rządzących w Auschwitz gdzie wszystkie matki z dziećmi od razu po przyjeździe szły do komór gazowych - opuszcza salę sądową, nieświadoma, że człowiek, którego uważała za zabójcę swojej rodziny, w rzeczywistości ocalił jej życie.

Dramat dotyczy więc kolejnych osób, co pogłębia rozmiar tragedii. Niemiecki historyk Nikolaus Wachsmann [2016: 625] w pracy poświęconej historii nazistowskich obozów koncentracyjnych na temat osoby Lucasa pisze:

Lekarz ss Franz Lucas, który wcześniej ochoczo brał udział w selekcjach w Auschwitz, na początku 1945 roku odmówił zrobienia tego samego w Ravensbrück. Po wojnie jego kolega nazwał tę zmianę uczuć cynicznym wybiegiem mającym mu zapewnić „bilet powrotny” do powojennego społeczeństwa.

Oczywiste wydaje się oczekiwanie na odpowiedź: wyrok sądu. Wcześniej jednak powraca pytanie o zakres i wymiar odpowiedzialności. Najpierw odpowiedzialności lekarza obozowego Lucasa, następnie świadków składających zeznania, odpowiedzialności sędziów, a także odpowiedzialności Czytelnika, którego Arendt 
zaprasza, a nawet zobowiązuje, by ową dramatyczną sytuację przemyślał z perspektywy osobistej. Czytelnik może zapytać: Jakie stanowisko zajmuje autor pracy? Odpowiadając na to pytanie, chcę wskazać na trzy sprawy.

Po pierwsze, jeśli przyjąć perspektywę Arendt, to myślenie, nawet w sprawie tak ważnej, jak walka o sprawiedliwość, nie może zostać wyparte przez negatywne, zaślepiające człowieka uczucia zemsty i odwetu. Mądrość dąży bowiem do przezwyciężenia zła, nie odpowiadając złem za zło, nienawiścią za nienawiść. Wyzwolenie od zaślepienia jest jednym z istotnych warunków myślenia odpowiedzialnego, zwłaszcza gdy chodzi o sprawiedliwość. Po drugie, dramatyczność sytuacji polega na tym, że z jednej strony byli świadkowie, którzy doświadczywszy w nieludzkich warunkach ludzkiego zachowania, oceniali Lucasa pozytywnie, natomiast $\mathrm{z}$ drugiej strony byli i tacy, którzy widzieli w postawie lekarza ss cynizm i wyrachowanie. Tej kwestii najprawdopodobniej nie da się jednoznacznie rozstrzygnąć. Należy z uwagą wysłuchać świadectw, które zostały złożone. Po trzecie, kolejne pytanie dotyczy decyzji o wstąpieniu Lucasa w szeregi ss. Osoba Hitlera, jeszcze przed zdobyciem władzy w 1933 roku, dzieliła ludzi na zwolenników i przeciwników nowej ideologii. Przeciwników pozbywano się w sposób kategoryczny. Totalitarna przemoc była faktem. Arendt słusznie przestrzega przed odpowiedzialnością zbiorową. Niemniej nie należy pomijać istotnego faktu, jakim była decyzja o wstąpieniu do ss, a więc do organizacji, której zadania Hitler sformułował już w 1930 roku. Była to jednostka powołana do niszczenia wewnętrznej opozycji, a później także zewnętrznych wrogów [Höhne 1990: 67]. Osoba wstępująca w szeregi ss nie może za ten wybór nie wziąć odpowiedzialności. I dotyczy to także Lucasa. Człowiek za swoje decyzje ponosi odpowiedzialność. Z pozoru banalna decyzja może okazać się kwestią życia lub śmierci - własnej lub innych. Podsumowując moją wypowiedź, chcę podkreślić, że nie chodzi bynajmniej o odniesienia teoretyczne, ale o przebudzenie własnej, indywidualnej odpowiedzialności. Arendt kształtuje poczucie odpowiedzialności nie tyle przez jej werbalizację, ile poprzez wezwanie do refleksji i przyjęcia konkretnej postawy moralnej (odpowiedzialność myślenia i działania). 
W Życiu umystu Arendt [2016: 23] formułuje wyznaczniki odpowiedzialnego myślenia:

Jeśli zdolność do odróżniania dobra od zła powinna się wiązać ze zdolnością myślenia, to musimy „żądać” jej uprawiania od każdego zdrowego na umyśle człowieka, czy jest on erudytą, czy ignorantem, czy jest inteligentny, czy głupi.

Trud myślenia jest zatem - na podobieństwo imperatywu Kanta - obowiązkiem każdego człowieka. Od owego obowiązku nie ma dyspensy ani ucieczki. Nawet niewinna próba częściowego przeniesienia odpowiedzialności na kogoś innego zawsze obarczona jest odpowiedzialnością. W refleksji Arendt odpowiedzialność ma charakter indywidualny i zarazem integralny (nieodłącznie związany z konkretnym człowiekiem):

A. „Istnieje coś takiego jak odpowiedzialność za rzeczy, których się nie zrobiło; można za nie odpowiadać. Ale nie ma czegoś takiego jak wina czy poczucie winy z powodu czegoś, co się wydarzyło bez naszego czynnego w tym udziału" [Arendt 2006: 176].

B. „Tam, gdzie wszyscy są winni, [tam - S.S.] nikt nie jest winny" [Arendt 2006: 61].

C. „Nie ma czegoś takiego jak wina zbiorowa. Pojęcia winy i niewinności mają sens tylko w odniesieniu do jednostek" [Arendt 2006: 62].

D. „Nie ma czegoś takiego jak posłuszeństwo w sprawach moralnych i politycznych, wyłączając sferę religijną” [Arendt 2006: 78].

Do rozstrzygnięcia pozostała wątpliwość, jak do sprawy winy i odpowiedzialności oskarżonego Lucasa odniósł się sąd? Oskarżony usłyszał wyrok: „Trzy lata i trzy miesiące ciężkich robót”. Sześciu oskarżonych skazano na dożywotnie pozbawienie wolności. Dziewięciu usłyszało wyrok od trzech i pół do czternastu lat pozbawienia wolności. Trzech oskarżonych uniewinniono. Skoro, jak zauważa Arendt, mamy prawo „żądać” uprawiania, czyli praktycznego wykorzystania, zdolności myślenia (a zatem odróżnienia dobra od zła) od każdego zdrowego na umyśle człowieka, pytanie o odpowiedzialność wydaje się skierowane do każdego z nas. 
Odpowiedzialność implikuje czynność myślenia, a to oznacza o wiele więcej niż zwykłą sprawność intelektu. Arendt wskazała różnice między czynnością intelektu a czynnością myślenia. Intelekt obejmuje przede wszystkim sferę zjawiskową i wyraża swoje poznanie $\mathrm{w}$ wiedzy (zjawiskowa strona świata). W czynności myślenia człowiek pyta przede wszystkim o sens, pyta nie tyle "Co?” i „Jak?", ile „Po co?” i „Jaki to ma sens?”.

Brak czynności myślenia można nazwać skandalem. Pojęcie $\sigma \kappa a$ ' $v \delta a \lambda o v$ oznaczało pułapkę, którą człowiek - jak się wydaje sam na siebie zastawia, ze wszelkimi tego konsekwencjami. Odpowiedzialność - jako konsekwencja myślenia - wzywa człowieka do troski o własne życie: jego formę, sposób, styl. Ideał życia autentycznego oznacza zgodność między myśleniem i działaniem. Model ten czerpie zarówno ze źródeł starogreckich (Sokrates), jak i judeochrześcijańskich (Chrystus), a nawiązują do niego Kant, Kierkegaard, Heidegger i in.

Człowiek [pisze Arendt, odnosząc się do Heideggera - S.S.] będący „strażnikiem” (Platzhalter) nicości, a przez to otwarty na nie-skrytość bycia, staje się teraz (to znaczy po zwrocie filozoficznym Heideggera) „stróżem” (Hüter) lub „pasterzem” (Hirte) bycia, a jego mowa daje byciu dom. [Arendt 2016: 377]

Myślenie wyraża się w mowie, o ile mowa nie jest jedynie pustą „gadaniną".

\section{Wnioski: wezwanie do myślenia i odpowiedzialności}

Myślenie (das Denken), określane w dziełach Arendt jako rozmyślanie (das Nachdenken), jest dla każdego człowieka podstawowym zadaniem, którego nie wolno zaniedbywać nawet wówczas, gdy inni się od niego uchylają. „Życie bez myślenia jest możliwe, traci jednak wtedy własną istotę - jest nie tylko bez znaczenia, lecz także nie w pełni żywe. Niemyślący są jak lunatycy" [Arendt 2016: 180]. Rozwijając myśl Autorki, warto zauważyć, że nic nie wyrządza w życiu człowieka takich szkód, jak bezmyślność. W nieobecności myślenia tkwi potworność, a zarazem banalność zła. Dobro i zło są skutkami działania, którego źródłem jest myślenie. 
Arendt [2006: 92] wskazuje, że „moralne postępowanie nie jest czymś oczywistym, ale wiedza o moralności, znajomość dobra i zła - tak”. Jest przekonana, że każdy zdrowy psychicznie człowiek może dostrzec różnicę pomiędzy dobrem a złem [Arendt 2006: 104-105]. Źródłem dobra jest pragnienie jego poznania, a ono oznacza czynność myślenia.

Dramat odpowiedzialności w refleksji filozoficznej Arendt wiąże się ściśle $\mathrm{z}$ dramatem myślenia. Jak zauważa Heidegger [2000: 12-13]:

[...] nawet fakt, że przez całe lata zajmujemy się rozprawami i pismami wielkich myślicieli, nie gwarantuje nam, że myślimy - ani nawet, że gotowi jesteśmy uczyć się myśleć. Przeciwnie: zajmowanie się filozofią może nas nawet najuporczywiej łudzić pozorami, że myślimy, bo przecież nieustannie „filozofujemy”. [...] Najbardziej poważne w naszym niepewnym czasie jest to, że jeszcze nie myślimy.

Jeśli diagnoza ta jest słuszna - a taką wydaje się wszędzie tam, gdzie obecne jest zło, nienawiść, przemoc, poniżenie, dyskryminacja - oznacza to dramatyczne wołanie o antidotum. Współczesny, nazywany nowoczesnym, człowiek potrzebuje inspiracji Arendt, domagającej się myślenia i rozmyślania - vita contemplativa. Okazuje się, że życie umysłu nie jest abstrakcją ani nawet wirtualną rzeczywistością, w której wydaje się zastępować je sztuczna inteligencja. Jest i pozostanie obowiązkiem, mającym swoje źródło w odpowiedzialności za życie - swoje i innych. Skoro więc cogito, ergo sum [Descartes 1988: 40], to także, a może przede wszystkim cogito, ergo sum reus. Myślę, więc jestem odpowiedzialny.

W konkluzji pracy, będącej zaledwie próbą inspiracji do użytecznej refleksji nad zagadnieniem myślenia i odpowiedzialności, warto przywołać pytanie: Co zatem stanowi istotę odpowiedzialności? Odpowiedzialność nie jest kwestią domagającą się jedynie teoretycznej odpowiedzi, leczjest świadomie przyjętym sposobem bycia, a ściślej: sposobem „stawania się”, który wymaga czynności umysłu i czynności woli - myślenia i działania. Propozycja Arendt [2010: 23], wyrażona w prologu do Kondycji ludzkiej, „jest zatem 
bardzo prosta: chodzi jedynie o to, byśmy pomyśleli nad tym, co robimy”. W praktyce myślenie oznacza, „że ilekroć napotykasz w życiu jakieś trudności, to za każdym razem musisz uruchamiać umysł na nowo" [Arendt 2016: 166]. Co więc łączy odpowiedzialność, a dokładniej odpowiedzialność za życie, z myśleniem? „Bez oddechu życia ludzkie ciało umiera; bez myślenia umysł ludzki jest martwy" [Arendt 2016: 121].

\section{Bibliografia}

Améry Jean (2007), Poza wina i kara, przeł. Ryszard Turczyn, posłowiem opatrzył Piotr Weiser, Homini, Kraków.

Arendt Hannah (1974), Osiemdziesięcioletni Heidegger, przeł. Henryk Krzeczkowski, „Znak”, nr 240, s. 691-701.

Arendt Hannah (2006), Odpowiedzialność i wtadza sądzenia, red. i wprowadzenie Jerome Kohn, przeł. Wojciech Madej, Mieczysław Godyń, posłowiem opatrzył Piotr Nowak, Prószyński i S-ka, Warszawa.

Arendt Hannah (2010), Kondycja ludzka, przeł. Anna Łagodzka, wstępem opatrzyła Margaret Canovan, Aletheia, Warszawa.

Arendt Hannah (2016), Życie umystu, przeł. Hanna Buczyńska-Garewicz, Robert Piłat, Bogdan Baran, Aletheia, Warszawa.

Burdon Peter (2017), Hannah Arendt: Legal Theory and the Eichmann Trial, Routledge, London.

Descartes René (1988), Rozprawa o metodzie, przeł. Wanda Wojciechowska, PWN, Warszawa.

Ettinger Elżbieta (1998), Hannah Arendt - Martin Heidegger, przeł. Elżbieta Wolicka, Znak, Kraków.

Heidegger Martin (1994), Bycie i czas, przeł., przedmową i przypisami opatrzył Bogdan Baran, PwN, Warszawa.

Heidegger Martin (2000), Co zwie się myśleniem?, przeł. Janusz Mizera, PWN, Warszawa-Wrocław.

Heidegger Martin (2002), Technika i zwrot, przeł. Janusz Mizera, Baran i Suszczyński, Kraków.

Heuer Wolfgang (1987), Hannah Arendt mit Selbstzeugnissen und Bilddokumenten, Rowohlt Taschenbuch Verlag, Hamburg.

Hey Dominik (2017), Der Eichmann-Prozess. Der Begriff des Handelns und seine Konsequenzen nach Hannah Arendt, Grin Publishing, München.

Höhne Heinz (1990), Der Orden unter dem Totenkopf. Die Geschichte der ss, Gondrom Verlag, Bindlach. 
Husserl Edmund (1975), Idee czystej fenomonologii i fenomenologicznej filozofii. Księga pierwsza, przeł. i przypisami opatrzyła Danuta Gierulanka, tłumaczenie przejrzał i wstępem poprzedził Roman Ingarden, PwN, Warszawa.

Platon (1999), Państwo, przeł. Władysław Witwicki, Alfa, Warszawa. Safranski Rüdiger (2008), Ein Meister aus Deutschland. Heidegger und seine Zeit, Carl Hanser Verlag, München.

Wachsmann Nikolaus (2016), Historia nazistowskich obozów koncentracyjnych, przeł. Maciej Antosiewicz, Świat Książki, Warszawa.

\section{Stefan Szary}

\section{The Problem of Thinking and Responsibility in Hannah Arendt's Philosophical Reflection}

The problem of responsibility became, particularly in the second half of the twentieth century, one of the most important subjects of philosophical reflection. Many thinkers, including Martin Heidegger, Emmanuel Lévinas, Karl Jaspers and Hans Jonas, expressed their views about it. The evil of totalitarian systems became the main experience triggering discussion about responsibility. The reflection included in Hannah Arendt's works is an important voice in the debate and it remains up-to-date despite the passage of time. Arendt demonstrated the multidimensional and dramatic character of responsibility by presenting the meanings of vita contemplativa and vita activa in reference to every person's existence. The thinker was searching for the answer to the question about the essence of responsibility. Today, she still introduces the readers of her works and the listeners of numerous interviews she gave to a more profound understanding of responsibility-related experiences. In my humble opinion, the greatest value of philosophical interpretation of Hannah Arendt's works is the fact that they still remain constructive reflections. Their influence is not limited to shaping one's mind only. It goes deeper and develops our attitudes, including the attitude to properly understood responsibility.

Keywords: thinking and acting; responsibility; totalitarian system; philosophy.

Stefan Szary - doktor nauk humanistycznych w dyscyplinie filozofii, wykładowca akademicki. Obszary zainteresowań naukowych: filozofia egzystencji, fenomenologia i hermeneutyka egzystencjalna. Autor książek: Człowiek - 
podmiot dramatu. Antropologiczne aspekty filozofi dramatu Józefa Tischnera (2005), Pytając o Boga. Refleksja z bt. Janem Pawtem II (2013), Szlakami Sørena Kierkegaarda. W dwusetna rocznicę urodzin filozofa (2013), Impresje egzystencjalne. Rozważania filozoficzne (2013), Mądrość Gór. Czternaście dni w Szklarskiej Porębie (2019). Adres e-mail: st.szary@gmail.com. 
